\title{
OPTIMIZATION OF ENZYMATIC SYNTHESIS OF ISOMALTO-OLIGOSACCHARIDES PRODUCTION
}

\author{
M.C. RABELO ${ }^{1}$, T.L. HONORATO ${ }^{1}$, L.R.B. GONÇALVES ${ }^{2}$, G.A.S. PINTO ${ }^{3}$ and \\ S. RODRIGUES ${ }^{1,4}$
}

\author{
${ }^{1}$ Departamento de Tecnologia de Alimentos \\ Universidade Federal do Ceará \\ Caixa Postal 12168, Bloco 858 Campus do Pici \\ 60021-970 Fortaleza, CE, Brazil \\ ${ }^{2}$ Departamento de Engenharia Química \\ Universidade Federal do Ceará \\ Bloco 709, Campus do Pici \\ 60455-760 Fortaleza, CE, Brazil \\ ${ }^{3}$ Embrapa Agroindústria Tropical \\ Laboratório de Bioprocessos \\ Rua Sara Mesquita, 2270 - Pici \\ Fortaleza, CE, Brazil
}

Accepted for Publication September 4, 2007

\begin{abstract}
Glucosyltransferases can be applied in the synthesis of prebiotic oligosaccharides. Enzymatic synthesis using acceptors can be used to obtain these carbohydrates. When maltose is the acceptor, oligosaccharides containing one maltose moiety and up to eight glucose units linked by $\alpha-1,6-$ glycosidic bonds are obtained as the product of dextransucrase acceptor reaction. In this work, the enzymatic synthesis of isomalto-oligosaccharides using dextransucrase from Leuconostoc mesenteroides NRRL B-512F was optimized by response surface methodology. The effect of maltose and sucrose concentrations on the acceptor reaction was evaluated in a batch reactor system. Partially purified enzyme was used to reduce the enzyme purification cost. The results showed that high sucrose concentrations in conjunction with high maltose levels enhanced the isomalto-oligosaccharide synthesis. A productivity of $42.95 \mathrm{mmol} / \mathrm{L}$.h of isomalto-oligosaccharides was obtained at the optimal operating condition $(100 \mathrm{mmol} / \mathrm{L}$ of sucrose and $200 \mathrm{mmol} / \mathrm{L}$ of maltose).
\end{abstract}

${ }^{4}$ Corresponding author. TEL: 55-85-3366-9656; FAX: 55-85-3458-3407; EMAIL: sueli@ufc.br 


\section{PRATICAL APPLICATIONS}

Oligosaccharides as prebiotic have a large application in food formulations, and their beneficial role in human health have been extensively studied. Although the acceptor mechanism of dextransucrase has already been extensively studied, an industrial process has not been developed yet for enzyme synthesis of isomalto-oligosaccharide. The process studied in this work allows the large-scale preparation of isomalto-oligosaccharide using partially purified enzyme.

\section{INTRODUCTION}

A prebiotic is a non-digestible food ingredient that selectively improves the host health by selectively stimulating the growth and/or the activity of one, or a limited number of bacteria in the colon (Kolida et al. 2002; Mussatto and Mancilha 2007). Oligosaccharides with a degree of polymerization between 2 and 8 have shown to significantly increase the growth of bifidobacteria in human intestine. Bifidobacteria are considered useful microorganisms that have an important role in maintaining human health and preventing the growth of microorganisms, which produce harmful substances such as amines and ammonia in the intestines. Prebiotic oligosaccharides are also advantageous as they are selectively utilized by bifidobacteria and are not used by noxious microorganisms such as Salmonella and Escherichia coli (Machida et al. 1986; Kaneko et al. 1994; Kohmoto et al. 1998; Chung and Day 2002; Chung and Day 2004). The use of prebiotic oligosaccharides in food is increasing (Mussatto and Mancilha 2007), owing to their health benefits.

Isomalto-oligosaccharides are composed by one maltose unit and up to eight glucose units linked by $\alpha-1,6$-glycosidic bonds with a chemical structure -(Glucose) $)_{n}$, where $\mathrm{n}=2$ to 8 (Sako et al. 1999; Mussatto and Mancilha 2007). These carbohydrates present prebiotic activity (Delzenne and Roberfroid 1994; Chung and Day 2002; Chung and Day 2004; Mussatto and Mancilha 2007). According to Sako et al. (1999), prebiotic oligosaccharides can be obtained by extraction, hydrolysis and enzymatic synthesis processes. Isomalto-oligosaccharides can be obtained by enzymatic hydrolysis of corn starch or by transglycosylation reaction (Delzenne and Roberfroid 1994; Monsan and Paul 1995; Pereira et al. 1998; Sako et al. 1999). Linear isomaltooligosaccharides with a degree of polymerization between 3 and 10 can be obtained by the acceptor reaction with dextransucrase (Tsuchiya et al. 1952; Demuth et al. 2002; Tanriseven and Dogan 2002; Kubik et al. 2004).

Dextransucrase (EC 2.4.1.5) is a bacterial extracellular glycosyl transferase, which catalyzes dextran synthesis. Fructose is a natural side product 
released when the enzyme polymerizes glucose from sucrose to form dextran. The high enzyme stability, under optimum synthesis conditions, allows its use on an industrial scale (Alsop 1993). When acceptors like maltose is used, short-chain oligomers are formed (Tsuchiya et al. 1952; Mayer et al. 1981; Paul et al. 1986; Pereira et al. 1998; Monchois et al. 1999). The yield and the degree of polymerization of these oligosaccharides depend on the availability of acceptors and sucrose in the reactor (Pereira et al. 1998; Rodrigues et al. 2005).

Although isomalto-oligosaccharides have several applications, an industrial enzyme process for large-scale production is still not available. Fermentation processes have been applied to produce prebiotic carbohydrates (Chung and Day 2002; Chung and Day 2004), but enzymatic synthesis yields higher productivities and is easier to control. The main aim of this work was to increase the production of isomalto-oligosaccharides using partially purified dextransucrase. The synthesis was optimized for high oligosaccharide concentration and high productivity.

\section{MATERIALS AND METHODS}

\section{Enzyme Preparation}

Leuconostoc mesenteroides NRRL B-512F was obtained from ARS Culture Bacterial Collection (NRRL Culture collection, United States Department of Agriculture, Peoria, IL). The strain was used to produce dextransucrase in a fed batch fermentation process. Culture medium was composed of sucrose, $50 \mathrm{~g} / \mathrm{L}$ (food grade); yeast extract, $20 \mathrm{~g} / \mathrm{L}$ (Merck, Darmstadt, Germany); $\mathrm{MgSO}_{4} .7 \mathrm{H}_{2} \mathrm{O}, 0.20 \mathrm{~g} / \mathrm{L} ; \mathrm{MnSO}_{4} .2 \mathrm{H}_{2} \mathrm{O}, 0.01 \mathrm{~g} / \mathrm{L} ; \mathrm{FeSO}_{4} .7 \mathrm{H}_{2} \mathrm{O}, 0.01 \mathrm{~g} / \mathrm{L}$; $\mathrm{CaCl}_{2} \cdot 2 \mathrm{H}_{2} \mathrm{O}, 0.02 \mathrm{~g} / \mathrm{L} ; \mathrm{NaCl}, 0.01 \mathrm{~g} / \mathrm{L}$; and $\mathrm{K}_{2} \mathrm{HPO}_{4}$ (anhydrous), $20 \mathrm{~g} / \mathrm{L}$.

A solution of $\mathrm{NaOH}(120 \mathrm{~g} / \mathrm{L})$ and sucrose $(300 \mathrm{~g} / \mathrm{L})$ was fed to the fermentor to control the $\mathrm{pH}$ and maintain the sucrose level in the culture medium. Fermentation was carried out in a BioFlo 3,000 fermentor (New Brunswick Scientific Co., Edison, NJ), with mechanical agitation speed of $150 \mathrm{rpm}$ and aeration of $0.5 \mathrm{~L} / \mathrm{min}$. The temperature of the fermentation was $30 \mathrm{C}$ and the $\mathrm{pH}$ was controlled at $6.7 \pm 0.1$ for $6 \mathrm{~h}$. After this period, the feed flow rate was interrupted and the $\mathrm{pH}$ was allowed to drop to 5.2 when the process was considered finished.

The cells were harvested by centrifugation $11,806 \times \mathrm{g}(8,000 \mathrm{rpm})$ for $10 \mathrm{~min}$. The enzyme was recovered from the culture broth by precipitation by adding one volume of a 50\% (p/v) polyethylene glycol (PEG 1500) solution, followed by centrifugation at $11,806 \times \mathrm{g}(8,000 \mathrm{rpm})$ for $10 \mathrm{~min}$ at $4 \mathrm{C}$. The partially purified enzyme was diluted in a $\mathrm{pH} 5.2$ sodium acetate buffer 
$(20 \mathrm{mM})$ containing $0.05 \mathrm{~g} / \mathrm{L}$ of $\mathrm{CaCl}_{2}$. Enzyme precipitation was done immediately after cell harvesting, as the enzyme in crude fermented broth is unstable (Rodrigues et al. 2003).

\section{Enzyme Activity Assay}

Enzyme activity was determined by quantifying the released fructose by the DNS (3,5-dinitrosalicylic acid) method (Miller 1959). The partially purified enzyme prepared as described above $(45 \mu \mathrm{L})$ was mixed with $455 \mu \mathrm{L}$ of a $10 \%(\mathrm{w} / \mathrm{v})$ sucrose solution in sodium acetate buffer $\mathrm{pH} 5.2(20 \mathrm{mM}$ containing $0.05 \mathrm{~g} / \mathrm{L}$ of $\mathrm{CaCl}_{2}$ ) and then incubated for $1 \mathrm{~h}$ at $30 \mathrm{C}$. Samples of $100 \mu \mathrm{L}$ were collected every $15 \mathrm{~min}$ and mixed with $100 \mu \mathrm{L}$ of the DNS reagent to stop the reaction. The enzyme activity was calculated by linear regression and expressed in $\mathrm{IU} / \mathrm{mL}$ (dextransucrase unit $/ \mathrm{mL}$ ). One international unit is defined as the amount of enzyme that releases $1 \mu \mathrm{mol}$ of fructose per minute under ideal reaction conditions (30C and $\mathrm{pH} 5.2$ ).

\section{Enzymatic Synthesis}

The synthesis was carried out using enzyme with $1 \mathrm{IU} / \mathrm{mL}$ in a $10-\mathrm{mL}$ glass batch reactor with temperature control, containing maltose and sucrose in different ratios according to a two-level central composite design with one central point (Table 1), where sucrose and maltose were the independent variables. The levels of the carbohydrates in the experimental planning were chosen based on the levels previously reported by Rodrigues et al. (2005), and considering a wide range of maltose/sucrose ratio as the initial concentration of each carbohydrate affects the amount of acceptor formed.

TABLE 1.

EXPERIMENTAL PLANNING, DEXTRAN (DXT), ISOMALTO-OLIGOSACCHARIDES (IMO) FORMATION AND OLIGOSACCHARIDE PRODUCTIVITY OBTAINED FROM EXPERIMENTAL PLANNING

\begin{tabular}{lcclll}
\hline Assay & $\begin{array}{l}\text { Sucrose } \\
(\mathrm{mmol} / \mathrm{L})\end{array}$ & $\begin{array}{l}\text { Maltose } \\
(\mathrm{mmol} / \mathrm{L})\end{array}$ & $\begin{array}{l}\text { DXT } \\
(\mathrm{mmol} / \mathrm{L})\end{array}$ & $\begin{array}{l}\text { IMO } \\
(\mathrm{mmol} / \mathrm{L})\end{array}$ & $\begin{array}{l}\text { Productivity } \\
(\mathrm{mmol} / \mathrm{L} . \mathrm{h})\end{array}$ \\
\hline 1 & 25 & 25 & $0.75 \pm 0.04$ & $11.79 \pm 0.66$ & 15.72 \\
2 & 25 & 200 & $0.61 \pm 0.04$ & $22.01 \pm 1.25$ & 29.35 \\
3 & 100 & 25 & $1.43 \pm 0.07$ & $18.74 \pm 1.04$ & 12.49 \\
4 & 100 & 200 & $1.09 \pm 0.07$ & $64.43 \pm 3.38$ & 42.95 \\
5 & 25 & 112.5 & $0.84 \pm 0.04$ & $18.48 \pm 1.01$ & 24.74 \\
6 & 100 & 112.5 & $1.30 \pm 0.07$ & $58.73 \pm 3.19$ & 39.45 \\
7 & 62.5 & 25 & $1.17 \pm 0.04$ & $13.88 \pm 0.80$ & 13.88 \\
8 & 62.5 & 200 & $0.93 \pm 0.07$ & $39.35 \pm 2.20$ & 39.35 \\
9 & 62.5 & 112.5 & $1.19 \pm 0.06$ & $38.15 \pm 1.89$ & 38.45 \\
10 & 62.5 & 112.5 & $1.21 \pm 0.07$ & $37.50 \pm 2.35$ & 37.50 \\
\hline
\end{tabular}


The synthesis was carried out till the sucrose added was completely utilized, calculated by enzyme activity definition and confirmed by highperformance liquid chromatography (HPLC) analysis. Dextran was precipitated by adding 3 volumes of $96 \%$ (v/v) ethanol. The supernatant was used to quantify the carbohydrates (HPLC), while the precipitated dextran was diluted in distilled boiling water and assayed as total carbohydrate after cooling to room temperature (Dubois et al. 1956; Rodrigues et al. 2005). All of the syntheses were carried out in duplicate and all analyses were done in triplicate.

\section{Product Analysis}

The supernatant containing isomalto-oligosaccharides, fructose and unreacted maltose was analyzed by HPLC with a Varian Pro Star system (Varian Inc., Palo Alto, CA) equipped with two high-pressure pumps model 210, refractive index detector model 350 and column oven Eldex $\mathrm{CH}$ model 150. Separation was achieved in an Aminex HPX-87C (300 mm $\times 7.8 \mathrm{~mm})$ column (Hercules, CA) at $85 \mathrm{C}$. Ultra pure water at $0.3 \mathrm{~mL} / \mathrm{min}$ was used as eluent, and the detector temperature was set at 45C (Honorato et al. 2007). Isomaltooligosaccharides were quantified by peak area using glucose as standard (Chung and Day 2002). The software ProStar WS 5.5 was used to acquire and process the data. Using the protocol described by Rodrigues et al. (2005), the degree of polymerization of the isomalto-oligosaccharides was assayed by thin-layer chromatography.

\section{Statistical Analysis}

Results were analyzed by response surface methodology. The software Statistica 5.0 (Statsoft) was used to generate the experimental planning and to process the data.

\section{RESULTS AND DISCUSSION}

HPLC analysis showed that maltose was not totally consumed in any of the assays. The viscosity of the medium strongly decreased when high maltose concentrations were used.

Table 1 shows the experimental planning and the results obtained as responses of the experimental design. Isomalto-oligosaccharides with a degree of polymerization up to 5 were obtained as illustrated in Fig. 1. Results for assays from 6 to 10 presented similar results.

Dextran production was not avoided in any of the assays. The results obtained showed that dextran concentrations were very low when compared with the values obtained for isomalto-oligosaccharides (Table 1). This low dextran value was expected as dextran synthesis is repressed when acceptors 


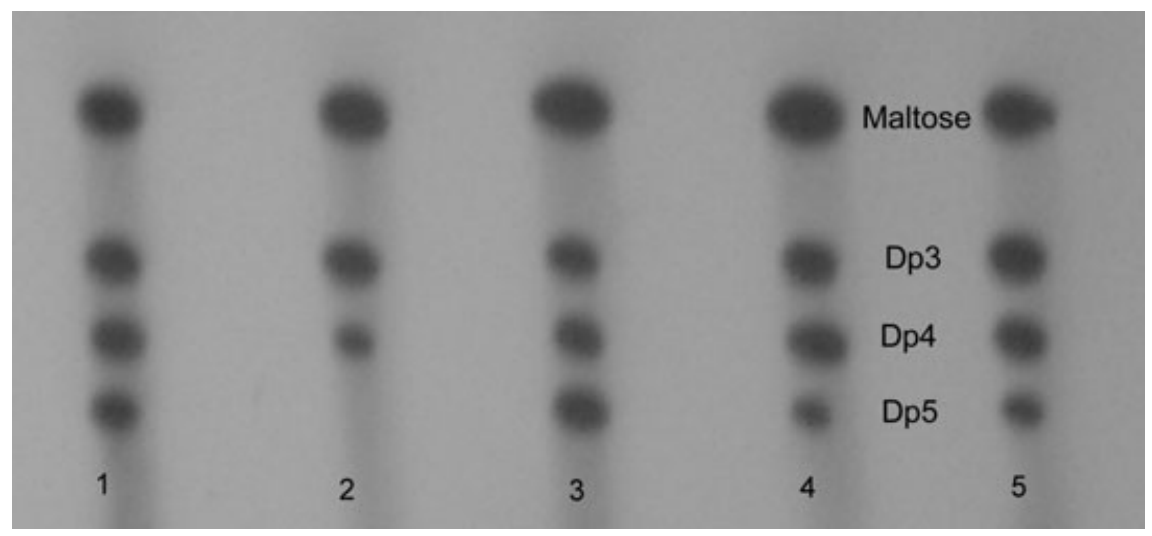

FIG. 1. THIN-LAYER CHROMATOGRAPHY ANALYSIS OF ISOMALTO-OLIGOSACCHARIDES OBTAINED BY ENZYMATIC SYNTHESIS

DP 3-5 denotes the degree of polymerization of the isomalto-oligosaccharide. Lanes 1-5 denote samples from assays $1-5$ in Table 1.

are present in the reaction medium (Rodrigues et al. 2005). The system was optimized considering isomalto-oligosaccharides formation and productivity. The effect of the independent variables on dextran formation was also investigated.

Table 2 presents the estimated effects on dextran and oligosaccharide formation and on isomalto-oligosaccharides productivity. Mean effect was significant in all analyzed responses. Only the interaction between sucrose and maltose concentration was not significant for dextran formation. Due to the repression of the dextran synthesis by the presence of acceptors (Rodrigues et al. 2005), both linear and quadratic effects of maltose concentration (ML and MQ), as well as the interaction between maltose and sucrose concentration, were negative on dextran synthesis. On the other hand, the linear effect of maltose and sucrose concentrations (SL and ML) were high and significant on isomalto-oligosaccharides synthesis. The quadratic effect (SQ) of sucrose concentration was not significant on isomalto-oligosaccharide synthesis. The fitted models for the studied responses as function of sucrose $(\mathrm{S})$ and maltose (M) concentrations are presented in Eqs. (1)-(3).

$$
\begin{aligned}
\operatorname{DXT}(\mathrm{mmol} / L)= & 3.00 \times 10^{-1}+1.79 \times 10^{-2} S-7.20 \times 10^{-5} \mathrm{~S}^{2}+3.15 \times \\
& 10^{-3} M-1.60 \times 10^{-5} M^{2}-1.50 \times 10^{-5} S \times M \\
\text { OLIG }(\mathrm{mmol} / L)= & 2.28-6.89 \times 10^{-3} S+1.31 \times 10^{-3} S^{2}+2.85 \times 10^{-1} M \\
& -1.32 \times 10^{-3} M^{2}+2.70 \times 10^{-3} S \times M
\end{aligned}
$$


TABLE 2 .

ESTIMATED EFFECTS OF SUCROSE AND MALTOSE CONCENTRATIONS ON DEXTRAN AND ISOMALTO-OLIGOSACCHARIDES CONCENTRATION AS WELL AS ON ISOMALTO-OLIGOSACCHARIDES PRODUCTIVITY

\begin{tabular}{|c|c|c|c|c|c|c|}
\hline \multirow[t]{2}{*}{ Factor } & \multicolumn{2}{|l|}{ Dextran } & \multicolumn{2}{|c|}{$\begin{array}{l}\text { Isomalto- } \\
\text { oligosaccharides }\end{array}$} & \multicolumn{2}{|c|}{ Productivity } \\
\hline & Effect & S.E. & Effect & S.E. & Effect & S.E. \\
\hline Mean & $1.19 *$ & 0.02 & $37.29 *$ & 2.75 & $36.50 *$ & 1.99 \\
\hline SL & $0.54 *$ & 0.03 & $29.87^{*}$ & 3.76 & $8.30 *$ & 2.72 \\
\hline SQ & $-0.20 *$ & 0.05 & 3.67 & 6.03 & -6.78 & 4.36 \\
\hline ML & $-0.24 *$ & 0.03 & $27.13^{*}$ & 3.76 & $23.19 *$ & 2.72 \\
\hline MQ & $-0.24^{*}$ & 0.05 & $20.31 *$ & 6.03 & $-17.34 *$ & 4.36 \\
\hline$S$ by $M$ & -0.1 & 0.04 & $17.73^{*}$ & 4.61 & 8.42 & 3.22 \\
\hline
\end{tabular}

* Significant at $95 \%$ of confidence level.

S.E., standard error; SL, sucrose concentration linear effect; SQ, sucrose concentration quadratic effect; ML, maltose concentration linear effect; $\mathrm{MQ}$, maltose concentration quadratic effect; $\mathrm{S}$ by $\mathrm{M}$, interaction between sucrose and maltose concentration.

$$
\begin{aligned}
\operatorname{Prod}(\mathrm{mmol} / \mathrm{L} . h)= & 1.40 \times 10^{-3}+2.68 \times 10^{-1} S-2.41 \times 10^{-3} \mathrm{~S}^{2}+3.67 \times \\
& 10^{-1} M-1.13 \times 10^{-3} M^{2}+1.28 \times 10^{-3} S \times M
\end{aligned}
$$

The $F$-value test was used as significance parameter for the models presented in Eqs. (1)-(3). Table 3 depicts the analysis of variance (ANOVA) for the regression models. According to the ANOVA analysis, the regression models were significant at $95 \%$ level of confidence as the calculated $F$-values were more than three times the listed $F$-value (Kalil et al. 2000). Satisfactory correlation coefficients $\left(R^{2}>0.96\right)$ were found for all the fitted models (Table 3). Figs. 2-4 present the surface response graphs obtained using the fitted models (Eqs. 1-3).

According to Fig. 2, dextran synthesis was maximized when high sucrose concentration $(>75 \mathrm{mmol} / \mathrm{L})$ and maltose concentrations below $125 \mathrm{mmol} / \mathrm{L}$ were used. Dextran synthesis was minimized when high maltose concentration $(200 \mathrm{mmol} / \mathrm{L})$ and low sucrose concentration $(<45 \mathrm{mmol} / \mathrm{L})$ was used. This behavior is in agreement with the repression mechanism of dextran of dextransucrase acceptor pathway synthesis as increasing acceptor concentration minimizes dextran synthesis and vice-versa (Rodrigues et al. 2005).

Isomalto-oligosaccharide synthesis was maximized when high maltose concentration $(>160 \mathrm{mmol} / \mathrm{L})$ and sucrose concentrations above $90 \mathrm{mmol} / \mathrm{L}$ were used. At low carbohydrate concentrations $(25 \mathrm{mmol} / \mathrm{L}$ of sucrose and $25 \mathrm{mmol} / \mathrm{L}$ of maltose), isomalto-oligosaccharides synthesis was minimized. At low sucrose concentration $(25 \mathrm{mmol} / \mathrm{L})$, increasing the maltose concentration up to $175 \mathrm{mmol} / \mathrm{L}$ slightly enhanced the oligosaccharide synthesis 
TABLE 3.

ANALYSIS OF VARIANCE OF THE FITTED MODELS

\begin{tabular}{|c|c|c|c|c|}
\hline Source of variation & $\begin{array}{l}\text { Sum of } \\
\text { squares }\end{array}$ & $\begin{array}{l}\text { Degrees of } \\
\text { freedom }\end{array}$ & $\begin{array}{l}\text { Mean } \\
\text { squares }\end{array}$ & $F$-value \\
\hline \multicolumn{5}{|l|}{ Dextran formation } \\
\hline Regression & 0.6038 & 5 & 0.1208 & 75.48 \\
\hline Residual & 0.0064 & 4 & 0.0016 & \\
\hline Total & 0.6102 & 9 & & \\
\hline Correlation coefficient & 0.9895 & & & \\
\hline$F$ listed value (95\%) & & & & $F_{5,4}=6.26$ \\
\hline \multicolumn{5}{|l|}{ Oligosaccharide formation } \\
\hline Regression & 2997.59 & 5 & 599.52 & 28.23 \\
\hline Residual & 84.96 & 4 & 21.24 & \\
\hline Total & 3082.55 & 9 & & \\
\hline Correlation coefficient & 0.9724 & & & \\
\hline$F$ listed value $(95 \%)$ & & & & $F_{5,4}=6.26$ \\
\hline \multicolumn{5}{|l|}{ Oligosaccharide productivity } \\
\hline Regression & 1212.07 & 5 & 242.41 & 21.85 \\
\hline Residual & 44.37 & 4 & 11.09 & \\
\hline Total & 1256.44 & 9 & & \\
\hline Correlation coefficient & 0.9647 & & & \\
\hline$F$ listed value (95\%) & & & & $F_{5,4}=6.26$ \\
\hline
\end{tabular}

(Fig. 3). On the other hand, at high sucrose concentration $(100 \mathrm{mmol} / \mathrm{L})$, increasing the maltose concentration up to $200 \mathrm{mmol} / \mathrm{L}$ strongly enhanced isomalto-oligosaccharides synthesis (Fig. 3). At concentrations of sucrose above $90 \mathrm{mmol} / \mathrm{L}$ and maltose above $150 \mathrm{mmol}$, the isomalto-oligosaccharide synthesis was maximized. The same condition also maximized the isomaltooligosaccharides productivity (Fig. 4).

For large-scale isomalto-oligosaccharide preparation, the optimum operating condition was obtained when high concentrations and high productivity were obtained simultaneously. High concentrations are desired, considering the product yield and purification. Sugars and isomalto-oligosaccharides are usually purified by chromatographic systems such as packed beds, fluidized bed and, recently, simulated moving bed. For the system under study, the optimum operating condition was maximum isomalto-oligosaccharides concentrations along with high productivity. Thus, the operating condition that maximized the isomalto-oligosaccharide synthesis, according to the experimental planning presented in Table 1 , was obtained using $100 \mathrm{mmol} / \mathrm{L}$ of sucrose and $200 \mathrm{mmol} / \mathrm{L}$ of maltose, obtaining a productivity of $42.95 \mathrm{mmol} /$ L.h (Fig. 4).

Despite lots of works on dextransucrase acceptor reaction that have been published, most of them were focused on the enzyme production, enzyme 


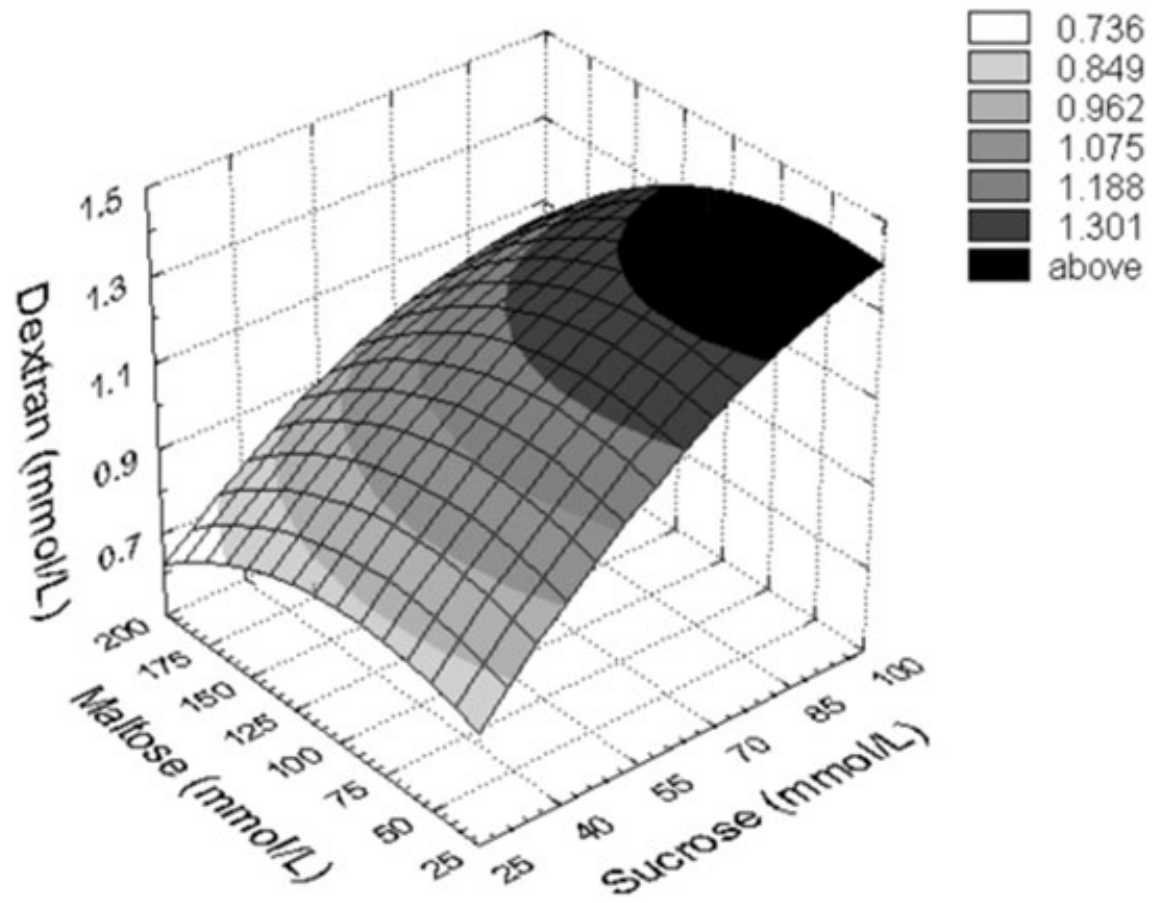

FIG. 2. FITTED SURFACE RESPONSE FOR DEXTRAN FORMATION

immobilization or on the molecular characterization of the acceptor product formed. Thus, the comparison of the results obtained herein to other published studies on oligosaccharides synthesis using dextransucrase acceptor reaction is difficult, because few data on the amount of the oligosaccharides production are available. Tanriseven and Dogan (2002) studied the synthesis of isomaltooligosaccharides using immobilized dextransucrase. Demuth et al. (2002) studied the acceptor reaction using unconventional acceptors, and Heincke et al. (1999) studied the acceptor mechanism of dextransucrase.

Kubik et al. (2004) obtained a productivity of $7.26 \mathrm{mmol} / \mathrm{L} . \mathrm{h}$ of isomalto-oligosaccharides using an immobilized mixture of dextransucrase and dextranase; Heincke et al. (1999) obtained a productivity of $35 \mathrm{mmol} / \mathrm{L} . \mathrm{h}$ of panose using purified dextransucrase. Chung and Day (2004) obtained a productivity of $55.6 \mathrm{mmol} / \mathrm{L}$ of oligosaccharides by fermentation with L. mesenteroides B-742.

The synthesis conditions used by the reported authors were different from the synthesis studied herein, and none of them used partially purified enzyme, making direct comparison not valid. 


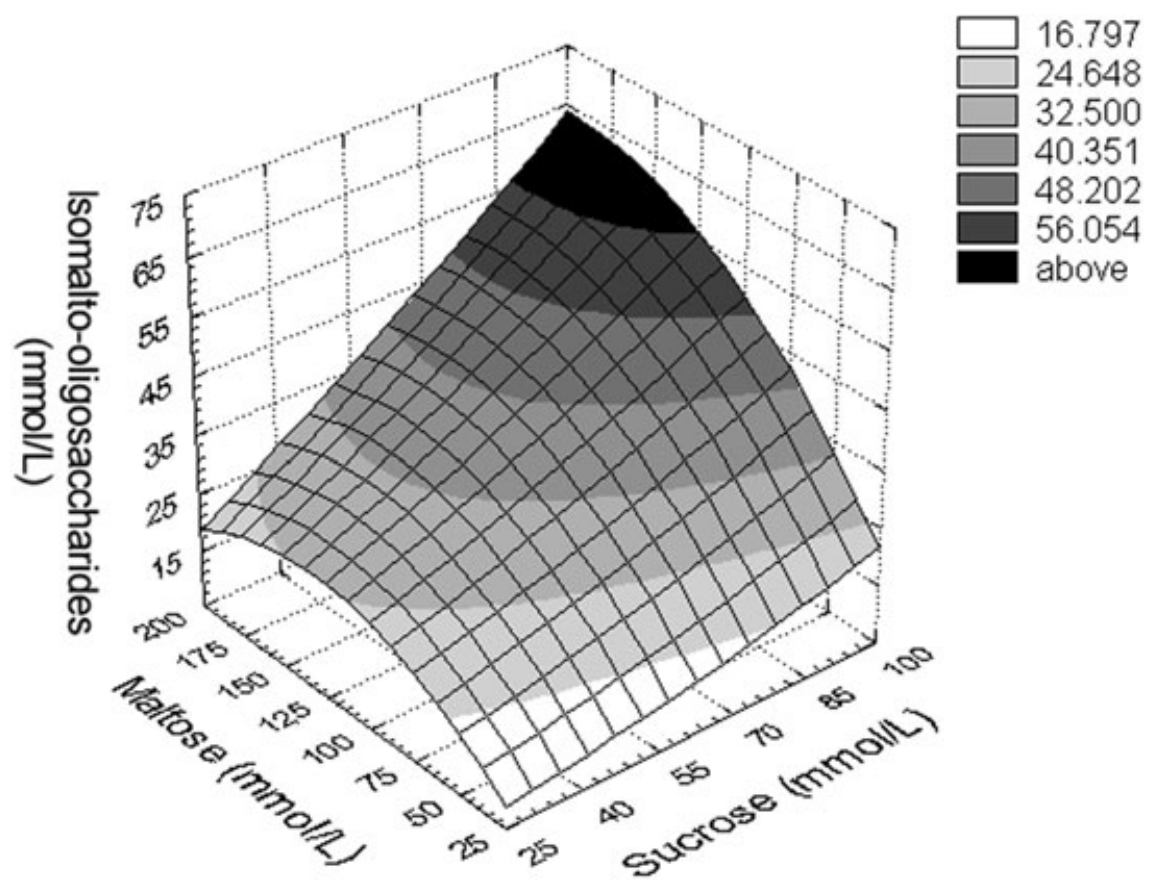

FIG. 3. FITTED SURFACE RESPONSE FOR ISOMALTO-OLIGOSACCHARIDE FORMATION

\section{CONCLUSION}

In this work, an enzyme batch system was optimized for isomaltooligosaccharide synthesis using partially purified dextransucrase from $L$. mesenteroides NRRL B-512F. The optimum operation condition was found when $200 \mathrm{mmol} / \mathrm{L}$ of maltose and $100 \mathrm{mmol} / \mathrm{L}$ of sucrose were loaded into the reactor with an enzyme activity of $1 \mathrm{IU} / \mathrm{mL}$. Under this condition, the process yielded $64.42 \mathrm{mmol} / \mathrm{L}$ of isomalto-oligosaccharides, with a productivity of $42.95 \mathrm{mmol} / \mathrm{L}$.h. High concentrations and productivity were obtained using a partially purified enzyme, which can lead to process cost reduction.

\section{ACKNOWLEDGMENTS}

The authors acknowledge CNPq for the awarded scholarship and the ARS Culture Collection for providing the microorganism. 


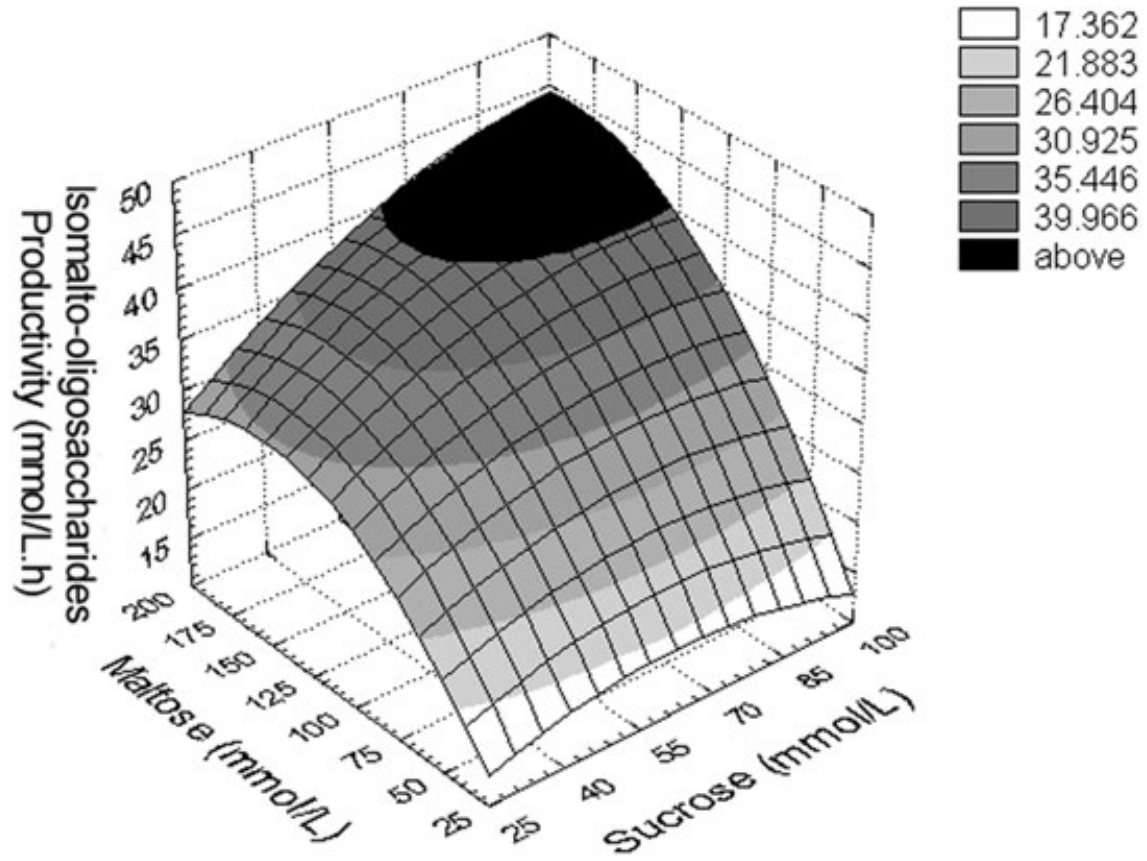

FIG. 4. FITTED SURFACE RESPONSE FOR ISOMALTO-OLIGOSACCHARIDES PRODUCTIVITY

\section{REFERENCES}

ALSOP, L. 1993. Industrial production of dextran. Prog. Ind. Microbiol. 18, $1-44$.

CHUNG, C.H. and DAY, D.F. 2002. Glucooligoasaccharides from Leuconostoc mesenteroides B-742 (ATCC 13146): A potential prebiotic. J. Ind. Microbiol. Biotechnol. 2, 196-199.

CHUNG, C.H. and DAY, D.F. 2004. Efficacy of Leuconostoc mesenteroides (ATCC 13146) isomaltooligosaccharides as a poultry prebiotic. Poultry Sci. Assoc. 83, 1302-1306.

DELZENNE, N.M. and ROBERFROID, M.R. 1994. Physiological effects of non-digestible oligosaccharides. Lebensm.-Wiss. Technol. 25, 1-6.

DEMUTH, K., JORDENING, H.-J. and BULCHOLTZ, K. 2002. Oligosaccharide synthesis by dextransucrase: New unconventional acceptors. Carbohydr. Res. 337, 1811-1820.

DUBOIS, M., GILLES, K.A., HAMILTON, P.A., REBERS, P.A. and SMITH, F. 1956. Colorimetric method for determination of sugars and related substances. Anal. Chem. 28, 350-356. 
HEINCKE, C., DEMUTH, B., JÖRDENING, H.J. and BUCHHOLTZ, K. 1999. Kinetics of the dextransucrase acceptor reaction with maltoseexperimental results and modeling. Enzyme Microbiol. Technol. 24, $523-$ 524.

HONORATO, T.L., RABELO, M.C., GONÇALVES, L.R.B., PINTO, G.A.S. and RODRIGUES, S. 2007. Fermentation of cashew apple juice to produce high added value products. World J. Microbiol. Biotechnol. 23, 1409-1415.

KALIL, S.J., MARUGERI, F. and RODRIGUES, M.I. 2000. Response surface analysis and simulation as a tool for bioprocess design and optimization. Process Biochem. 35, 539-550.

KANEKO, T., KOHMOTO, T., KIKUCHI, H., SHIOTA, M., IINO, H. and MITSUKA, T. 1994. Effects of isomlatooligosaccharides with different degrees of polymerization on human faecal Bifidobacteria. Biosci. Biotechnol. Biochem. 58, 2288-2290.

KOHMOTO, T., FUKUI, F., TAKAU, H., MACHIDA, Y., ARAI, M. and MITSUOKA, T. 1998. Effect of isomalto-oligosaccharide on human faecal flora. Bifidobacteria Microf. 77, 61-69.

KOLIDA, S., TUOHY, K. and GIBSON, G.R. 2002. The human gut flora in nutrition and approaches or its dietary modulation. BNF. Nutr. Bull. 25, 223-231.

KUBIK, C., SIKORA, B. and BIELECK, S. 2004. Immobilization of dextransucrase and its use with soluble dextranase for glucooligosaccharides synthesis. Enzyme Microbial. Technol. 34, 555-560.

MACHIDA, Y., FUKUI, F. and KOMOTO, T. 1986. Use of oligosaccharides for promoting the proliferation of bifidobacteria. European Patent 0242459.

MAYER, R.M., MATTHEUS, M.M., FUTERMAN, C.L., PARNAIK, V.K. and JUNG, S.M. 1981. Dextransucrase: Acceptor substrate reactions. Arch. Biochem. Biophys. 208, 278-287.

MILLER, G.L. 1959. Use of dinitrosalicilic acid reagent for determination of reducing sugar. Anal. Chem. 31, 426-428.

MONCHOIS, V., WILLEMONT, R.M. and MONSAN, P. 1999. Glucansucrases: Mechanism of action and structure function relationships. FEMS Microbiol. Rev. 23, 131-151.

MONSAN, P. and PAUL, F. 1995. Enzymatic synthesis of oligosaccharides. FEMS Microbiol. Rev. 16, 187-192.

MUSSATTO, S.I. and MANCILHA, I.M. 2007. Non-digestible oligosaccharides: A review. Carbohydr. Polym. 68, 587-597.

PAUL, F., ORIOL, E., AURIOL, D. and MONSAN, P. 1986. Acceptor reaction of a highly purified dextransucrase with maltose and oligosaccha- 
rides: Application to the synthesis of controlled-molecular-weight dextrans. Carbohydr. Res. 149, 433-441.

PEREIRA, A.M., COSTA, F.A.A., RODRIGUES, M.I. and MAUGERI, F. 1998. In vitro synthesis of oligosaccharides by acceptor reaction of dextransucrase from Leuconostoc mesenteroides. Biotechnol. Lett. 20, 397-401.

RODRIGUES, S., LONA, L.M.F. and FRANCO, T.T. 2003. Effect of phosphate on production of Leuconostoc mesenteroides NRRL B-512F. Bioprocess Biosys. Eng. 23, 57-62.

RODRIGUES, S., LONA, L.M.F. and FRANCO, T.T. 2005. The effect of maltose on dextran yield and molecular weight distribution. Bioprocess Biosyst. Eng. 28, 9-14.

SAKO, T., MATSUMOTO, K. and TANAKA, R. 1999. Recent progress on research and applications of non-digestible galacto-oligosaccharides. Int. Dairy J. 9, 69-80.

TANRISEVEN, A. and DOGAN, S. 2002. Production of isomaltooligosaccharides using dextransucrase immobilized in alginate fibres. Process Biochem. 37, 1111-1115.

TSUCHIYA, H.M., HELLMAN, N.N. and KOEPSELL, H.J. 1952. Factors affecting molecular weight of enzymatically synthesized dextran. J. Am. Chem. Soc. 75, 757-758. 